\title{
The use of clinical photography by UK general dental practitioners
} demography of clinical photography use by general dental practitioners (GDPs).

- Identifies the most popular uses of clinical photography.

- Looks at the reasons cited for use and non use of clinical photography by GDPs.

\author{
G. A. Morse, ${ }_{1}^{1}$ M. S. Haque, ${ }^{2}$ M. R. Sharland ${ }^{3}$ and F. J. T. Burke ${ }^{4}$
}

\author{
VERIFIABLE CPD PAPER
}

\begin{abstract}
Aim The aim of this study was to assess by means of a postal questionnaire the numbers of general dental practitioners (GDPs) who used clinical photography and for what application. Method The questionnaire was distributed to 1,000 randomly selected dentists in the UK with an explanatory letter and reply paid envelope. The data collected was computerised and analysed statistically. Results Five hundred and sixty-two replies were received. Of the respondents, 48\% used clinical photography, with 59\% using a digital camera, 34\% a $35 \mathrm{~mm}$ camera and 19\% a video camera. Principal uses of clinical photography were treatment planning (84\%), patient instruction/motivation (75\%), medico-legal reasons (71\%) and communication with the laboratory (64\%). Conclusion Clinical photography was used by $48 \%$ of general dental practitioner respondents.
\end{abstract}

\section{INTRODUCTION}

Clinical dental photography has a number of uses, which include: ${ }^{1-12}$

- Documentation

- Medico-legal purposes

- Clinical assessment

- Patient education

- Case planning

- Patient motivation and co-operation

- Marketing

- Facilitation of communication between operator and technician

- Staff training

- Demonstration and education purposes for the operator and between clinicians

- Diagnosis

- Restoration performance

- Personal interest and satisfaction

- Recording possessions and for insurance purposes.

\footnotetext{
${ }^{1 * G e n e r a l ~ D e n t a l ~ P r a c t i t i o n e r, ~ H i l l t o p ~ D e n t a l ~ S u r g e r y, ~}$ 1007 Bristol Road South, Northfield, Birmingham, B31 20T; ${ }^{2}$ Medical Statistician, Primary Care Clinical Sciences, University of Birmingham, Edgbaston, Birmingham, B15 2TT: ${ }^{3}$ Head of Multimedia Services, ${ }^{4}$ Professor of Primary Dental Care, University of Birmingham, St Chads Queensway, Birmingham B4 6NN *Correspondence to: Greg A. Morse Email: gregmorse@tiscali.co.uk
}

\section{Online article number E1}

Refereed Paper - accepted 9 October 2009

DOI: 10.1038/sj.bdj.2010.2

${ }^{\circ}$ British Dental Journal 2010; 208: E1
Although not mandatory, the importance of photography as a clinical, administrative and marketing tool suggests that its use should be widespread in the UK. Developments in digital photographic technology have facilitated the integration of photography into clinical dentistry as many practitioners have access to a computer. These facilitate practice administration and reduce dependency on paper records. Computerisation, coupled with software, enables the manipulation and storage of digital images and transfer of data over the Internet. The most recent study on the use of photography in clinical dentistry in the UK was carried out in 2002, ${ }^{13}$ so it was considered that a further study was timely.

The aims and objectives of this study were therefore:

- To determine the proportion and demographics of UK dental practitioners who use clinical photography

- To ascertain its uses in dental practices

- To determine the reasons why nonusers do not make use of clinical photography

- To determine the use of computers in clinical photography by UK-based practitioners.

This mirrored the aims of the 2002 study. ${ }^{13}$ In this previous study it was found that clinical photography was used by $36 \%$ of general dental practitioner respondents. Males, specialist and private practitioners, and practitioners from the Midlands were more likely to be users of clinical photography. Principal reasons for use were patient instruction, interest and medicolegal reasons. Only 8\% had attended a course on dental photography. ${ }^{13}$

In the 2002 study $62 \%$ of respondents were using an intra-oral $35 \mathrm{~mm}$ camera and 32\% a digital camera. Of the 64\% respondents who did not use clinical photography, 54\% considered that they would use it at some time in the future.

In (35 mm) chemical photography, the film sheet serves as the light sensitive sensor, storage and reproduction medium so there is little scope for manipulation. In digital photography each of these three entities uses different media, facilitating manipulation and unparalleled flexibility in editing, copying and disseminating images. The high quality yet instantaneous image production make them superior to the relatively inexpensive Polaroid instant cameras with long economy possible by reusing storage media such as memory cards. Digital photography is environmentally greener by eliminating toxic dyes and processing chemicals, and the film for instant cameras is expensive. ${ }^{14}$ Good quality clinical pictures are of course possible 
with $35 \mathrm{~mm}$ cameras using appropriate macro-lenses.

Disadvantages of digital photography include the initial capital outlay and constantly changing technology, with an initial steep learning curve that may appear daunting. Clinical photography is, however no more daunting than many clinical procedures. ${ }^{15}$ Digital technology appears to be here to stay along with digital broadcasting, digital consumer goods and digital radiography. ${ }^{14}$

The digital single lens reflex (DSLR) camera with a high quality lens is considered the ideal choice for dental photography, as it is capable of taking portraits as well as close up or macro images of the dentition, by through-the-lens viewing and metering, precise focusing and accurate framing. ${ }^{16}$ Intra-oral or fibre optic cameras are a useful tool for the demonstration of patients' oral problems on a monitor. However, the quality may be insufficient for permanent documentation or for archiving. ${ }^{15}$

The clinical practice of dentistry is a very visual and hands-on discipline. Clinical video photography can be used as an effective marketing and educational tool. In one study, undergraduates taught using real-time video produced more accurately tapered preparations. This ability was retained over one year. ${ }^{17}$ Video photography may not only facilitate compliance with CPD requirements, but also familiarise clinicians with technical procedures. Videotaping a dental examination following a traumatic injury can optimise documentation. Standardisation of photographic shots is helpful with documentation and presentation. ${ }^{18}$

Transfer of digital images onto a computer and then over the Internet dramatically optimises their usefulness clinically, educationally, medico-legally and from a marketing perspective. The dynamic interplay between dental, photography, computerisation and the Internet is demonstrated by websites such as www.locateAdoc.com, where clinical before and after shots are posted to promote dentists and procedures. YouTube hosted a two and a half minute video demonstration on standard dental photographic views by Dr Thomas Hedge (www.tomhedge.com) posted in February 2007, also advertising private courses and DVDs on dental photography. Another good example, which is also an interactive website, is www.thedigitaldentist-site.org. uk. This gives advice on technical procedures as well as recommending suitable equipment, including photographic equipment. The availability of privately run courses and associated DVDs was not researched at the time of the postal questionnaire.

\section{METHOD}

A questionnaire was designed using many of the questions from the 2002 study. ${ }^{13}$ These were repeated with the permission of the authors so that comparisons could be made.

Questions were devised to quantify the use and attitude of general dental practitioners (GDPs) towards clinical photography, and to relate their usage to the type of practice, age and gender of the practitioner. These questions had originally been piloted among 10 GDPs. ${ }^{13}$

The questionnaire, accompanied by a prepaid envelope and a letter explaining the project, was sent by post to 1,000 randomly selected UK dentists using data from the Medlist Database (www.medlist. co.uk), a company specialising in providing mailing lists for all areas of medicine, biology, science and technology. Random selection was achieved by this methodology. The larger list of dentists was first de-duplicated on the postcode field and then further reduced to 1,000 random records. This was achieved by placing the postal codes into a column in an Excel spreadsheet and the random number formula copied into each cell of the adjacent column. The columns were linked and the random number field sorted randomly to produce a random sort of the postcodes, the first 1,000 of which were then selected in the database.

In an attempt to improve the response to the second mailing a request letter was personally addressed to the recipient, explaining again the relevance of the research and the importance of receiving an adequate number of responses in order to make the study useful. As the study was designed to be anonymous, the second mailing had to be sent again to the entire sample of 1,000 dentists and was printed on pink paper to identify it from the first mailing in which the questionnaires were green.

The data were then entered onto an SPSS (SPSS Inc.) database for analysis, sorted and cross-checked against the relevant questionnaires to identify and correct erroneous data entries. Frequency analysis using descriptive statistics and then cross tabulation in SPSS were used to identify demographic associations. Confidence level calculation was completed using the formula recommended ${ }^{19}$ to assess the reliability of the data. The statistical significance of associations was tested using Chi square tests with appropriate followup multiple comparisons to evaluate late response bias.

Sample size calculation was performed. To detect a prevalence of 36\% (the percentage of respondents who used photography in the previous study) ${ }^{13}$ with 5\% precision and 95\% confidence, 354 responders were calculated to be required.

In addition, 15 postgraduate deaneries (Table 1) were contacted by phone to confirm the availability or otherwise of courses on dental photography in their region. The information received was collated manually. The availability of privately run courses in the UK was not researched.

\section{RESULTS}

As all respondents did not answer every question, total numbers responding to each question varied.

\section{General and demographic data}

Replies were received from 562 dentists, a response rate of $56.2 \%$. In the first mailing $38.0 \%(\mathrm{n}=382)$ responded, with a further $18.0 \%(\mathrm{n}=180)$ after the second mailing. Male respondents amounted to $71.4 \%$ ( $\mathrm{n}=399)$.

On the question of using photography, 536 valid responses were received. Of these 384 were from male responders and the rest, 152, were from female responders. Of the responders, 212 male and 57 female dentists used clinical photography.

Regarding years since graduation, 3.8\% ( $\mathrm{n}=22$ ) had graduated between 0 and 5 years previously, 12.7\% ( $\mathrm{n}=71)$ had graduated between 6 and 10 years previously, 25\% ( $\mathrm{n}=140)$ between 11 and 20 years ago and 55.8\% ( $\mathrm{n}=314)$ more than 21 years ago. Single-handed practitioners amounted to $31.4 \%(n=190)$ of the respondents.

Regarding practice location, 45.3\% ( $\mathrm{n}=252$ ) of the respondents' practices were in a city or town centre 


\section{Table 1 Availability of courses in clinical photography}

\begin{tabular}{|c|c|c|c|}
\hline Deanery & Address & Website & Course/Title \\
\hline Eastern & $\begin{array}{l}\text { Postgraduate Dental Office } \\
\text { Eastern Deanery Block } 3 \\
\text { Ida Darwin Suite, Fulbourn } \\
\text { Hospital, Cambridge CB1 5EE }\end{array}$ & www.easterndeanery.org & $\begin{array}{l}\text { 'Smile please! The art and science of dental } \\
\text { photography' }\end{array}$ \\
\hline Kent, Surrey \& Sussex & $\begin{array}{l}\text { The KSS Postgraduate Deanery } \\
7 \text { Bermondsey Street } \\
\text { London SE1 2DD }\end{array}$ & www.dental.kssdeanery.org & $\begin{array}{l}\text { 'Photography in dental practice' } \\
\text { 'Clinical photography' }\end{array}$ \\
\hline London & $\begin{array}{l}\text { London Deanery } \\
20 \text { Guildford Street } \\
\text { London WC1N 1DZ }\end{array}$ & www.londondeanery.ac.uk & $\begin{array}{l}\text { 'Clinical photos, jaw recording in good practice } \\
\text { clinical record keeping' }\end{array}$ \\
\hline Mersey & $\begin{array}{l}\text { Department of Postgraduate } \\
\text { Dental Education } \\
\text { First Floor, Hamilton House } \\
24 \text { Pall Mall, Liverpool L3 6AL }\end{array}$ & www.merseydeanery.nhs.uk & None \\
\hline Northern & $\begin{array}{l}\text { Postgraduate Institute for } \\
\text { Medicine and Dentistry } \\
10-12 \text { Framlington Place } \\
\text { Newcastle-upon-Tyne NE2 4AB }\end{array}$ & www.pimd.co.uk & 'Dental photography to produce a case report' \\
\hline Northern Ireland & $\begin{array}{l}\text { Northern Ireland Medical and } \\
\text { Dental Training Agency } \\
5 \text { Annadale Avenue, Belfast } \\
\text { Northern Ireland BT17 3JH }\end{array}$ & www.nimdta.gov.uk & None \\
\hline North Western & $\begin{array}{l}\text { North Western Deanery } \\
\text { 4th Floor, Barlow House } \\
\text { Minshull Street } \\
\text { Manchester M1 3DZ }\end{array}$ & www.nwpgmd.nhs.uk & None \\
\hline Oxford & $\begin{array}{l}\text { The Department of Postgraduate } \\
\text { Medical and Dental Education } \\
\text { The Triangle, Roosevelt Drive } \\
\text { Headington, Oxford OX3 7XP }\end{array}$ & www.oxdent.ac.uk & None \\
\hline Scotland & $\begin{array}{l}\text { NHS Education for Scotland } \\
\text { 2nd Floor, Hanover Buildings } \\
66 \text { Rose Street } \\
\text { Edinburgh EH2 2NN }\end{array}$ & www.nes.scot.nhs.uk/dentistry & $\begin{array}{l}2 \text { courses for dentists } \\
2 \text { courses for DCPs }\end{array}$ \\
\hline South West & $\begin{array}{l}\text { Dental Postgraduate Department } \\
\text { Bristol Dental Hospital } \\
\text { The Chapter House } \\
\text { Lower Main Street } \\
\text { Bristol BS1 2LY }\end{array}$ & www.swdentalpg.net & None \\
\hline South Yorkshire \&t East Midlands & $\begin{array}{l}\text { Regional Postgraduate } \\
\text { Dental Office } \\
\text { Don Valley House } \\
\text { Savile Street East } \\
\text { Sheffield S4 7U0 }\end{array}$ & www.pgde-trent.co.uk & None \\
\hline Wales & $\begin{array}{l}\text { Dental Postgraduate Department } \\
\text { Grove Mews, } 1 \text { Coronation Road } \\
\text { Birchgrove CF14 40Y }\end{array}$ & www.dentalpostgradwales.ac.uk & 'Digital photography' \\
\hline Wessex & $\begin{array}{l}\text { NHS Wessex Deanery } \\
\text { Highcroft, Romsey Road } \\
\text { Winchester SO22 5DH }\end{array}$ & www.wessex.org.uk/dental & None \\
\hline West Midlands & $\begin{array}{l}\text { The Postgraduate Office } \\
\text { School of Dentistry } \\
\text { St Chad's Queensway } \\
\text { Birmingham B4 6NN }\end{array}$ & www.postgrad-dentistry.bham.ac.uk & $\begin{array}{l}\text { 'Techniques of improving your image, } \\
\text { Part I and Part II' } \\
\text { e-course and forum }\end{array}$ \\
\hline Yorkshire & $\begin{array}{l}\text { The Department for NHS } \\
\text { Postgraduate Medicine } \\
\text { and Dental Education } \\
\text { Willow Terrace Road } \\
\text { University of Leeds } \\
\text { Leeds LS2 9TJ }\end{array}$ & www.yorkshiredeanery.com & None \\
\hline
\end{tabular}

location, $38.4 \%(\mathrm{n}=213)$ were in a suburban location and $16.2 \%(\mathrm{n}=90)$ in a rural location.
Regarding practice type, $40.4 \%(n=224)$ of the respondents practices were 'mainly National Health Service (NHS)', 34.1\%
( $\mathrm{n}=189)$ were 'mainly private' and $25.5 \%$ ( $n=141$ ) were 'mixed NHS and private'. Specialist practices amounted to $11 \%$ 
( $\mathrm{n}=61$ ), with a majority of these [59\% ( $n=36)$ ] being orthodontic specialists.

Regarding attendance at postgraduate courses or meetings during the year preceding the survey, $1.8 \%(\mathrm{n}=10)$ stated that they had attended no courses, $11.4 \%(n=63)$ had attended one to two courses, 20.5\% $(\mathrm{n}=114)$ had attended three to four courses and 66.3\% ( $n=368$ ) had attended five or more. Of the respondents who had attended courses, 15.9\% $(n=86)$ had attended a course on dental photography. Listed in Table 1 are deanery courses in May 2007.

Clinical photography in some form was used by $48 \%(\mathrm{n}=270)$ of respondents. Of these, 34.4\% ( $\mathrm{n}=93)$ used a $35 \mathrm{~mm}$ camera, with 59.3\% ( $\mathrm{n}=160)$ using digital photography. A further 18.9\% $(\mathrm{n}=51)$ used a video camera.

The most stated perceived advantage for different photographic systems were reasonable cost, ease of use and the good quality of results achieved. The most frequently stated disadvantages of camera systems were that the camera system was bulky, time consuming, complicated, produced poor quality images and was expensive.

\section{Uses of dental photography}

The uses for which respondents used their photographic equipment are shown in Table 2, with treatment planning, followed by patient instruction and motivation, being the most frequently quoted uses.

When asked to rate the usefulness of clinical photography for a variety of purposes, the respondents provided replies as indicated in Table 3, with medico-legal purposes and patient instruction/motivation considered the most useful.

Regarding the frequency of use of clinical dental photography, 54\% of users of photography $(n=168)$ photographed one to five cases per week, 14.1\% $(n=46)$ photographed six to ten cases per week and 15.4\% ( $n=48$ ) photographed more than ten cases. Photographs were stored most frequently on a computer [48.36\% ( $\mathrm{n}=118)], 29.5 \%$ ( $\mathrm{n}=72$ ) were stored in patient records and $3.7 \%(\mathrm{n}=9)$ in photographic files. Digital images were stored on a computer by $78.7 \%$ ( $n=212)$ of respondents.

With regard to future usage, 91.9\% ( $n=248$ ) of respondents who used photography considered that they would use clinical photography more in the future.

\section{Table 2 Uses of clinical photography in practice cited by respondents}

\begin{tabular}{l|l|l|l}
\hline Use & Number & Overall \% & $\%$ of photography users \\
\hline Patient instruction/motivation & 202 & 35.9 & 75.1 \\
\hline Treatment planning & 227 & 40.4 & 84.0 \\
\hline Communication with laboratory & 173 & 30.8 & 64.0 \\
\hline Medico-legal reasons & 194 & 34.5 & 71.8 \\
\hline Restoration performance & 163 & 18.3 & 60.3 \\
\hline Teaching & 91 & 16.2 & 33.7 \\
\hline Marketing & 134 & 23.8 & 49.6 \\
\hline Interest & 176 & 31.3 & 65.1 \\
\hline Other purposes & 44 & 7.8 & 16.2 \\
\hline
\end{tabular}

\section{Table 3 Usefulness of clinical photography indicated by respondents}

\begin{tabular}{l|l|l}
\hline Use & \% very useful overall & $\%$ very useful of photography users \\
\hline Medico legal purposes & 27 & 56.2 \\
\hline Patient instruction/motivation & 26.5 & 55.1 \\
\hline Teaching & 17.6 & 36.6 \\
\hline Interest & 19.9 & 41.4 \\
\hline Treatment planning & 22.8 & 47.4 \\
\hline Liaison with laboratory & 19.6 & 40.7 \\
\hline Recording restoration performance & 10.9 & 22.5 \\
\hline Marketing & 21.4 & 44.4 \\
\hline Other reasons & 3.7 & 7
\end{tabular}

\section{Table 4 Reasons given for not using clinical photography}

\begin{tabular}{l|l|l}
\hline Reason & $\%$ overall & $\%$ of those not using photography \\
\hline No perceived need/demand & 27.6 & 58.1 \\
\hline High capital cost & 14.4 & 30.3 \\
\hline Too time consuming & 19.8 & 41.4 \\
\hline Don't know what's involved & 10.3 & 21.6 \\
\hline Have no interest in photographs & 6.0 & 12.6 \\
\hline Poor fees for photographs in NHS & 21.0 & 44.0 \\
\hline Infection control risk & 3.2 & 6.7 \\
\hline Other & 7.5 & 15.6
\end{tabular}

Clinical effectiveness was thought to be enhanced by $85.2 \%(n=242)$ of respondents who used photography.

\section{Associations between use of clinical photography and demographic factors}

There was no evidence of a significant association between use of clinical photography and practice location ( $\mathrm{p}=0.263$ ), whether the practice was single-handed or group ( $\mathrm{p}=0.144$ ), or whether respondents replied to the first or the second mailing $(p=0.218)$. On the question of using photography, 536 valid responses were received. Three hundred and eighty-four of these were from male responders and the rest, 152, were from female responders. 
Among the 384 male responders, 212 (55.2\%, 95\% CI 50.2\%-60.1\%) indicated that they use photography. Among the 152 female responders, 57 (37.5\%, 95\% CI $30.2 \%-45.5 \%$ ) indicated that they use photography. As the two confidence intervals do not overlap, we may conclude that male dentists are more likely to use photography compared to female dentists.

There was some evidence of an association between use of clinical photography and years since graduation, with those graduated most recently (0-5 years) and those graduated longest ( $>20$ years) being less likely to use clinical photography than those who had graduated between 6 and 20 years ago $(\mathrm{p}<0.001)$. Principals and vocational dental practitioners (VDPs) were significantly more likely to use clinical photography than respondents who were associates or who held 'other' positions in the practice ( $p=0.003)$.

There was a significant association between use of clinical photography and type of practice (NHS or private), with a greater proportion of respondents in private practice being users of clinical photography than respondents from mixed NHS/private or solely NHS practices ( $p<0.001$ ). The percentage of respondents in mixed practices who used clinical photography was significantly greater than the percentage using clinical photography in NHS practices ( $\mathrm{p}<0.001)$.

The use of clinical photography in specialist practices was significantly greater than in general practices ( $p<0.001)$. Individuals who had attended courses on clinical photography were more likely to use clinical photography ( $p<0.001)$. Those already using clinical photography were prepared to spend more $(\mathrm{p}<0.001)$ on a new system.

\section{Non-users of dental photography}

Reasons for not undertaking clinical photography are listed in Table 4. The main reason stated was no perceived need or demand, by $58.1 \%(n=155)$. The other main reasons were poor fees by $44.0 \%$ ( $\mathrm{n}=118$ ), too time consuming by $41.4 \%$ ( $\mathrm{n}=111$ ) and high capital cost by $30.3 \%$ $(\mathrm{n}=81)$. Of the respondents who did not use clinical photography ( $\mathrm{n}=278), 56.1 \%$ ( $n=156$ ) felt that they would commence using clinical photography at some time in the future, with $68.2 \%(n=107)$ estimating that they would commence taking clinical photographs within two years, and 31.8\% $(n=50)$ within five years.

\section{DISCUSSION}

The method used in this research was a postal questionnaire, a research method used frequently in dentistry. ${ }^{20}$ That almost all of the questions were answered by $100 \%$ of responders suggests that the questionnaire was easily understood.

The response rate of 56\% was lower than the $76 \%$ rate of the previous (similar) study. ${ }^{13}$ There may be several reasons for this. It is possible that research performed by postal questionnaires is perceived as time-consuming and intrusive, particularly with the increasing amount of paper work expected of most dentists and dental specialists. Additionally, over the past three years there have been major changes in UK dentistry with many GDPs pre-occupied with units of dental activity (UDAs) and working with the new NHS contract at the time when the questionnaire was distributed.

Some of the results mirrored those found previously in 2002.13 An example of this was that users of clinical photography, as demonstrated in Table 2, considered dental photography useful for a number of reasons, with treatment planning, patient instruction and medico-legal reasons most popular. Reasons for not using photography were similar to those given in the 2002 study, ${ }^{13}$ with a significant number of dentists seeing no demand or need. Lack of time, high cost and poor remuneration were seen as further obstacles to using photography, as in the 2002 study $^{13}$ (Table 4). Despite this, it was encouraging to note that 56\% considered that they would commence using clinical photography at some time in the future, with $68 \%$ of these within the next two years. This last finding also mirrored the trend in the 2002 study, ${ }^{13}$ in which $51 \%$ of non-users considered that they would commence clinical photography at some point in the future. In this respect, since an increased number of respondents stated that they were using clinical photography, it may be considered that some of the earlier respondents actually did start using clinical photography in the time since the previous survey.

As expected the use of digital photography was predominant, being used by 59\% of clinical photographers, although $34 \%$ of clinical photographers still used a $35 \mathrm{~mm}$ camera. This is in contrast to the 2002 study in which a majority of respondents used $35 \mathrm{~mm}$ cameras with only 20\% using a digital camera. The growth in digital over five years is therefore dramatic.

Compared to the 5\% in previous 2002 study, ${ }^{13} 16.1 \%$ of respondents had been on a course on dental photography in the previous year. This is still a low percentage and, considering that $48 \%$ of respondents used clinical photography, it suggests that there is a need and probably a demand for a greater number of postgraduate courses than currently available in most deaneries (Table 1).

It was suggested by Sarll and Holloway ${ }^{21}$ that 'failure to make changes which might improve practice profitability as well as those promoting their own and their staff and patients' welfare appeared to relate to lack of information'. It could, however, be suggested that lack of time to properly consider information also results in a failure to make changes.

This paper, and the previous study,,$^{13}$ have shown that photography is more often used by men. Whether this is reflected in other areas of technology can only be surmised. To some extent, this may explain why use of clinical photography was more likely if you were a male practitioner. A significant proportion of the dental profession is female. The percentage of female dentists in the Medlist UK dental database was $36.3 \%$ (8,440 dentists). ${ }^{22}$

\section{CONCLUSIONS}

- Forty-eight percent of respondents used some form of clinical photography

- Private and specialist practitioners were more likely than practitioners in mixed NHS/private practice to use clinical photography. NHS practitioners were the least likely to use clinical photography ( $p<0.001)$

- Male practitioners were more likely than female practitioners to use clinical photography ( $\mathrm{p}<0.001$ )

- Medico-legal uses, patient instruction and motivation were cited as the most useful benefits of photography

- No perceived need, lack of time and poor fees under the NHS were the reasons given most frequently for not 
using clinical photography

- Digital photography was used by 59.2\%, $35 \mathrm{~mm}$ by $34.4 \%$ and a video system by $18.8 \%$ of users

- $16.1 \%$ had been on a photography course in the last year

- Considering the number of dentists using photography and intending to in the near future, there is a relative paucity of courses available nationally run by the deaneries.

Thanks are due to the practitioners who responded. Thanks are also due to Mrs Lynda Malthouse at the University of Birmingham School of Dentistry for printing the questionnaires and Ms Tracey Carter at Hilltop Dental Surgery, together with Peter, Felicity and Eloise Morse, for collating the data.

1. Benjamin S, Aguisre A, Drinnan A. Digital photography enables better soft tissue screening diagnosis and case acceptance. Dent Today 2002; 21(11): 116-121.
2. Wander P. Photography 1: uses in general dental practice. Dent Update 1983; 11: 297-304.

3. Vargas M A. Use of photographs for communicating with the laboratory in indirect posterior restorations. J Prosthodont 2002; 11: 208-210.

4. Dalin J B. Digital photography and imaging can enhance practice in several ways. J Indiana Dent Assoc 2002-2003; 81: 24-26.

5. Erten H, Uctasli M B, Akarslan Z Z, Uzun O, Semiz $M$. Restorative treatment decision making with unaided visual examination, intraoral camera and operating microscope. Oper Dent 2006; 31: 55-59.

6. Goldstein M B. Digital photography in your general dental practice. The why's, how's, and wherefore's. Dent Today 2003; 22(4): 98-101.

7. Freedman G. Intraoral cameras: patient education and motivation. Dent Today 2003; 22(4): 144-151.

8. Amet $E_{1}$ Milana J. Restoring soft and hard dental tissues using a removable implant prosthesis with digital imaging for optimum dental esthetics: a clinical report. Int J Periodontics Restorative Dent 2003; 23: 269-275.

9. Burns J S. Digital imaging. How candid use of a camera can promote your practice. Dent Today 2003; 22(6): 56-59.

10. Sandler J, Murray A. Digital photography in orthodontics. J Orthod 2001; 28: 197-201.

11. Christensen G J. Important clinical uses for digital photography. J Am Dent Assoc 2005; 136: 77-79.
12. Samaras $C$. Intraoral cameras: the value is clear. Compend Contin Educ Dent 2005: 26(6A Suppl): 456-458.

13. Sharland M, Burke FJ T, McHugh S, Walmsley A D. Use of dental photography by UK dental practitioners. Dent Update 2004; 31: 199-202.

14. Ahmad I. Digital dental photography. Part 3: principles of digital photography. Br Dent J 2009; 206: $517-523$

15. Ahmad I. Digital dental photography. Part 1: an overview. Br Dent J 2009; 206: 403-407.

16. Ahmad I. Digital dental photography. Part 4: choosing a camera. Br Dent J 2009; 206: 575-581.

17. Robinson $P$ B, Lee J W. The use of real time video magnification for the pre-clinical teaching of crown preparations. Br Dent J 2001; 190: 506-510.

18. Bengel W. Standardisation in dental photography. Int Dent J 1985; 35: 210-217.

19. Altman D G, Machin D, Bryant T N, Gardner M J (eds). Statistics with confidence. 2nd ed. pp 46. London: BMJ Books, 2000.

20. Tan R T, Burke F J T. Response rates to questionnaires mailed to dentists. A review of 77 publications. Int Dent J 1997; 47: 349-354.

21. Sarll D, Holloway P J. Factors influencing innovation in general dental practice. Br Dent J 1982; 153: 264-266.

22. Nash P of Medlist. Personal communication December 2007. 